\title{
Primary lymphoedema
}

\author{
Kiyoshi Shikino, Masatomi lkusaka
}

General Medicine, Chiba University Hospital, Chiba, Japan

\section{Correspondence to} Dr Kiyoshi Shikino, kshikino@gmail.com, kshikino@yahoo.co.jp

Accepted 14 July 2018

\section{Check for updates}

(C) BMJ Publishing Group Limited. No commercial re-use. See rights and permissions. Published by BMJ.

To cite: Shikino $\mathrm{K}$ Ikusaka M. BMJ Case Rep Published Online First: [please include Day Month Year]. doi:10.1136/bcr-2018 225843

\section{DESCRIPTION}

A 32-year-old woman presented with a 20-year history of slowly progressive leg oedema with recurrent cellulitis. She was referred from her primary care physician. Her mother had the same condition. Physical examination revealed non-pitting bilateral leg oedema (figure 1). Stemmer's sign was positive. Lymphoscintigraphy showed non-visualisation of inguinal nodes $30 \mathrm{~min}$ postexercise and dermal backflow in the lower limbs (figure 2). Compression garments were used but failed. She underwent bilateral lower limb supermicrosurgical lymphaticovenular anastomosis (two times anastomosis and four times incisions) and her oedema markedly improved. Four years after the operation, she was well without relapse.

Primary lymphoedema is due to a congenital and/or inherited condition associated with pathological development of the lymphatic vessels. Lymphoedema praecox is the most common form of primary lymphoedema and generally occurs during puberty or pregnancy with onset prior to age 35 years. ${ }^{1}$ It is found in about 1 in 100000 male and 1 in 400000 female, and $10 \%$ of cases are familial with an autosomal dominant inheritance pattern. ${ }^{1}$ The most common presentation is oedema of the foot or ankle. ${ }^{2}$ Lymphoedema is an important risk factor for cellulitis. Testing for Stemmer's sign consists of trying to lift the skin over the second toe. If the skin cannot be lifted, Stemmer's sign is positive. A positive Stemmer's sign is indicative of lymphoedema because the high protein and fat contents of lymph fluid induce fibrosis. ${ }^{3}$ Differential diagnosis of lymphoedema is lipoedema, which occurs from hip to ankle, usually sparing the feet. ${ }^{3}$ Lymphoscintigraphy and

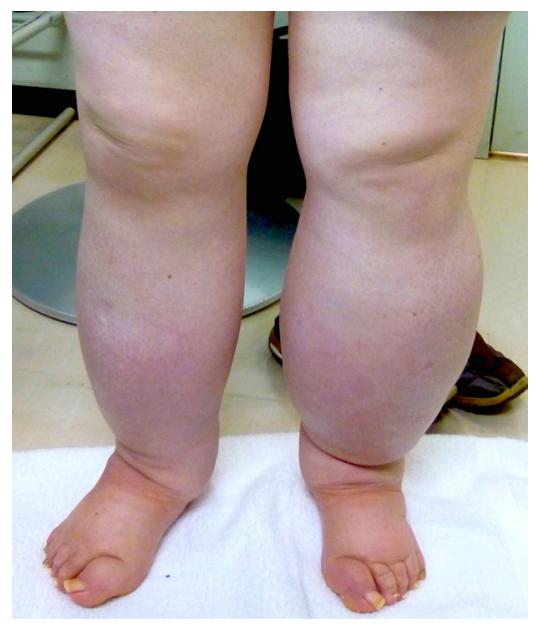

Figure 1 Non-pitting bilateral leg oedema.

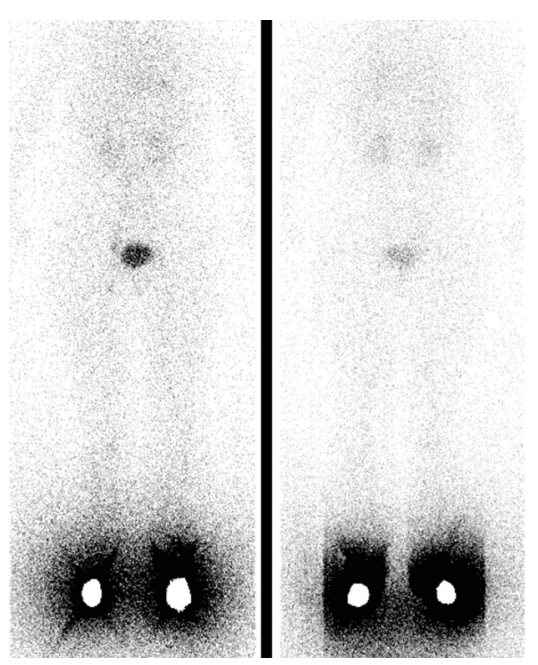

Figure 2 Preoperative lymphoscintigraphy. Lymphoscintigraphy revealed no migration of radiopharmaceutical agent in the lower limbs.

lymphangiography are useful imaging modality to rule out lymphoedema as a cause of leg swelling. Ultrasonography can be used to evaluate the lymphatic and venous systems, such as deep vein thrombosis and arteriovenous fistula. CT and MRI are accessible to detect causes of obstructive secondary lymphoedema. Supermicrosurgical lymphaticovenular anastomosis is assumed to have a valuable place in the treatment of lymphoedema.

\section{Learning points}

Stemmer's sign is indicative of lymphoedema.

- Differential diagnosis of lymphoedema is lipoedema, usually sparing the feet.

Contributors $\mathrm{KS}$ and $\mathrm{MI}$ managed patient. KS wrote the draft. MI revised this article.

Funding The authors have not declared a specific grant for this research from any funding agency in the public, commercial or not-for-profit sectors.

Competing interests None declared.

Patient consent Obtained.

Provenance and peer review Not commissioned; externally peer reviewed.

\section{REFERENCES}

1 Harel L, Amir J, Nussinovitch M, et al. Lymphedema praecox seen as isolated unilateral arm involvement: case report and review of the literature. J Pediatr 1997;130:492-4.

2 Lewis JM, Wald ER. Lymphedema praecox. J Pediatr 1984;104:641-8.

3 Schook CC, Mulliken JB, Fishman SJ, et al. Differential diagnosis of lower extremity enlargement in pediatric patients referred with a diagnosis of lymphedema. Plast Reconstr Surg 2011;127:1571-81. 
Copyright 2018 BMJ Publishing Group. All rights reserved. For permission to reuse any of this content visit http://group.bmj.com/group/rights-licensing/permissions.

BMJ Case Report Fellows may re-use this article for personal use and teaching without any further permission.

Become a Fellow of BMJ Case Reports today and you can:

- Submit as many cases as you like

- Enjoy fast sympathetic peer review and rapid publication of accepted articles

Access all the published articles

- Re-use any of the published material for personal use and teaching without further permission

For information on Institutional Fellowships contact consortiasales@bmjgroup.com

Visit casereports.bmj.com for more articles like this and to become a Fellow 